\title{
Marketing Strategy of Family Welfare Education Student's Products and Service of Unsyiah in Digital Era
}

\author{
Fadhilah $^{1}$, Jenni Mastura ${ }^{2}$ and Fanny Nailufar ${ }^{3}$ \\ \{jenimastura@yahoo.com $\left.{ }^{2}\right\}$ \\ ${ }^{1}$ Family Welfare Education Department \\ ${ }^{2}$ Education and Teacher Training Faculty \\ ${ }^{3}$ Syiah Kuala University of Darussalam, Banda Aceh, Indonesia
}

\begin{abstract}
Strategy is a plan that is prepared, coordinated and implemented with certain steps and effort to achieve a goal. One of the most important aspects in business is the aspect of marketing, it can be rationalized into thinking i.e. success in business is generally determined by success in marketing, and the marketing itself is considered as a major component of success from the accuracy and effectiveness of implementing marketing strategy. This study is done as a way to know "Marketing Strategy of Family Welfare Education Student's Products and Service of Unsyiah in Digital Era ". The aim of this study is to describe the marketing strategy of family welfare education students of Unsyiah products and services that have been done and developed in the digital era. The method that is used in this study is a qualitative approach. The data in this study sourced from the student's business products that have run a personal business at least for six months. The data collection techniques that used in this study are observation, note taking, and documentation. The observation itself includes observation, interview, and documentation. Based on the results of data analysis, the findings of this study can be showed as follows. Family welfare education student of Education and Teacher Training Faculty of Unsyiah still use conventional marketing strategy in their business, the owners are not able to optimize social media that can be developed as a marketing tool in the digital era. The conclusion of this study is the entrepreneurship that has been run by the student by using conventional marketing strategy is good enough. It proved by the number of consumer and increasing of income in every month, but it still less effective if not optimizing the digital marketing strategy considering the growing era is really fast at this time.
\end{abstract}

Keywords:Strategy, Marketing, Family Welfare Education Student of Unsyiah.

\section{Introduction}

In an era of business competition that is increasingly competitive like today, every businessman certainly wants his business to continue to run in accordance with the times. Previously marketed products have been made through a quality process with various features that can improve customer satisfaction, thus customers are willing and to re-enjoy what is 
offered by the business so that they become loyal customers in running a business to be competent, besides showing how to distribute it, this is not easy to do because to distribute a product, marketing management is needed in accordance with the times, so that the products we produce are quickly recognized by the market.

Effective marketing requires planning, phasing plans, concepts and strategies for market segmentation, good and mature marketing strategies and planning. Marketing strategies for goods and services through the media can use advertising as a means of promotion. Advertising requires media as a means, such as newspapers, magazines, radio, television and online media. [1] stated that, "Marketing is a process when a product or service is defined so that it has a brand value and personal image. Marketing also includes the process of advertising, direct mail (postal offers), and other techniques to increase people's awareness of a product or service. "The Family Welfare Education Department is one of the departments under the scope of the Teacher Training and Education Faculty, Syiah Kuala University. The Family Welfare Education Department was established in 1976 and has two majors, namely culinary art (Tata Boga) and fashion (Tata Busana). In this department the students are not only taught to be teachers, but also students are taught to be able to compete in the world of work. This study program is not only guided students to master theories and practices in the field of expertise in various business worlds through work practices.

The vision of The Family Welfare Study Program as an academic institution is to make the leading Family Welfare Study program of Teacher Training and Education Faculty of Syiah Kuala University family in 2026 in the field of cooking and fashion education in order to produce quality, ethical and moral human resources.

In accordance with the vision and mission that are expected so far there have been many efforts being developed by The students of Family Welfare Study program of Teacher Training and Education Faculty of Syiah Kuala University, in accordance with their respective fields, some of which have opened businesses such as selling hoods (veils), graduation sling, graduation makeup, women's Muslim clothing sewing services, various cake and so on.

It is appropriate for the students of Family Welfare Study program of Teacher Training and Education Faculty of Syiah Kuala University to promote with a good strategy in order to meet effective goals. The promotion must be in accordance with the conditions of the students of Family Welfare Study program of Teacher Training and Education Faculty of Syiah Kuala University. Where the available funds must be taken into account with the benefits obtained by promotional activities organized by the students of Family Welfare Study program of Teacher Training and Education Faculty of Syiah Kuala University. As it is known that the state of the world business is dynamic, which always experiences changes that occur at any time and there is a connection between one another.

Therefore marketing strategies have a very important role for success. Besides that the applied marketing strategy must be reviewed and developed in accordance with the development of the market and the market environment. the author sees Family Welfare Study Program of Teacher Training and Education Faculty of Syiah Kuala University students are still using traditional strategies in running their business in terms of marketing their products and services. With the development in this digital era, there are so many new marketing strategies that can be developed by the students of Family Welfare Study program of Teacher Training and Education Faculty of Syiah Kuala University. Seeing the importance of marketing strategies to increase the sales volume of products and services of the students of Family Welfare Study program of Teacher Training and Education Faculty of Syiah Kuala University, the authors are interested in to conduct a further research entitled "Marketing Strategy of Products and Services of the students of Family Welfare Study program of Teacher Training and Education Faculty of Syiah Kuala University in the Digital Era". 
The problem formulation in this study was to find out how the marketing strategy of products and services of the students of Family Welfare Study program of Teacher Training and Education Faculty of Syiah Kuala University in the Digital Era was done.

The research objective was to find out:

1. To know the marketing strategy of the products and services of Family Welfare Study Program of Teacher Training and Education Faculty of Syiah Kuala University students that was done

2. To find out the marketing strategy of products and services that can be developed by Family Welfare Study Program of Teacher Training and Education Faculty of Syiah Kuala University students in the digital era

\section{Research Methodology}

Strategy is a plan that has been prepared and then coordinated and implemented with certain steps that have been planned with an effort to achieve a goal. According to Muhyi et al (2016: 30) "Strategy is a very important effort carried out by important people who realize that long-term goals can only be achieved with a creative and innovative plan and activity carried out continuously". In a good strategy there is coordination of the work team, having a topic, identifying supporting factors that are in accordance with the principles of implementing ideas rationally, efficiently in funding, and having tactics to achieve goals effectively. The above definition shows that the strategy here explains a few points. First, what must be achieved? Second, it is about resources and what kind of activity will be allocated for each market product in determining environmental opportunities and challenges and to achieve excellence. Third, strategies used must be considered, selected and adapted to organizational goals. In other words it can be said that the strategy is a tool to achieve organizational goals in relation to long-term goals, follow-up programs, and resource allocation priorities. So that the strategy is a very important tool to achieve competitive advantage.

One of the most important aspects of business is the marketing aspect, this aspect can be rationalized into a thought that success in business is determined by success in marketing, and in marketing itself it is considered that the main component of the success of marketing is the accuracy and effectiveness in implementing the marketing strategy. [2]. "Marketing is a social and managerial process where individuals and groups get their needs and desires by creating, offering and exchanging something of value to each other" [3]. In addition, the established marketing strategy must be reviewed and developed in accordance with the development of the market and the market environment. Thus, the marketing strategy must be able to provide a clear and directed picture of what the company will do in using opportunities or chances in several target markets. In this case, a very important and interrelated part is needed, to achieve the success of marketing activities carried out by a company, namely the target market and the marketing reference (marketing mix) for the target market [4].

Marketing mix is a key concept in modern marketing theory, [5] states that "the marketing mix is a set of marketing tools used by companies to achieve their marketing goals in the target market" Marketing mix is a tool for marketers which consists of various elements of a marketing program that need to be considered so that the implementation of the specified marketing and positioning strategies can be successful. Marketing mix of goods products includes $4 \mathrm{p}$, namely: product, price, place, promotion Products are all things that can be offered by producers to be noticed, asked, looked for, bought, used, or consumed by the market as fulfilling the needs or desires of the market. The products offered by the Family Welfare Study Program of Teacher Training and Education Faculty of Syiah Kuala University 
students include physical items (such as headscarves, various cake, graduation sling etc).

Family Welfare Study Program of Teacher Training and Education Faculty of Syiah Kuala University students who run their entrepreneurship have gone through the process of creating a new product that is introduced to the community, the distribution of time and effort were done maximally as the students are active student of Family Welfare Study Program of Teacher Training and Education Faculty of Syiah Kuala University. Then the risks and finances faced are also not easy, because their readiness to be an entrepreneur is to have satisfaction and freedom in creating (creation) works and selling them

In terms of advancing their business, they only need consistency and willingness or desire to promote the work that has been created. As an effort to make people recognize the products they offer and have a selling value that is equivalent to the quality of the products produced, thus the community will be more satisfied by having the goods. It needs an interesting way to promote a product to stimulate buyers to have their products, with the unique appearance of a promotion technique, it will attract public interest.

In the digital era like today, competition among businessmen is increasingly high and requires businessmen to hone their creativity in creating new innovations, producing good quality products and good sales strategies. This needs to be done to attract the interest of consumers and to generate maximum profits. The profits will be used to develop existing businesses in order to become large and in other words, the larger businesses will need more workers.In this digital era, the development of technology is an evolution in media technology, say new media or people commonly call it online media or people are more familiar with the term internet, this media is certainly very familiar. This media is also touted as a medium that until now no one has matched the number of users.

Information Technology is a technology used to process data, including processing, obtaining, compiling, storing, and manipulating data in various ways to produce quality information that is relevant, accurate and timely information, which is used for personal, business [6] One of the types of information technology is social media, meanwhile [7] says "Social media is an online media where users can easily participate, share and create content including blogs, social networks, wikis, forums and other virtual worlds. Blogs, social networks and wikis may be the most common forms of social media used by people around the world.The development of information technology that occurs raises the term ECommerce, which means the process of buying and selling products, services and information carried out electronically by using a computer network and the network used is the internet network. Digital Marketing is one of the marketing methods that is currently developing very rapidly. Digital marketing itself refers to the method of marketing by utilizing electronic equipment such as computers and smartphones to interact with consumers. The application of digital marketing itself usually refers more to various technologies that use the internet such as e-mail, social networks and websites. The digital marketing method also uses other electronic equipment models such as radio, TV channels, billboard on the main roads and many more.

The method used in this study was qualitative descriptive which was aimed to examine the current situation that is related to the marketing strategy of products and services of Family Welfare Study Program of Teacher Training and Education Faculty of Syiah Kuala University students in the digital era. Research was conducted through collecting data from natural settings by utilizing the problems under study which are descriptive and tend to use analysis with an inductive approach. Qualitative research uses an inductive approach. Thus, the actual theory was tested with the data and instruments of the researcher [8]. Qualitative research methods are also called artistic methods, because the research process is more artistic (less patterned), and is called an interpretive method because the data of research results are more related to the interpretation of data found in the field [9] Qualitative research is a research procedure that produces descriptive data in the form of words and images, the data is obtained 
from interviews, field notes, photographs, records, notes or memos, and other official documentation. Qualitative research methods are also called naturalistic methods because the situation of research fields are natural or genuine as they are, without being manipulated, arranged by experiment or test. The research was carried out in May 2018, after obtaining permission from the assistant in the Academic Field of the Teacher Training and Education Faculty of the Syiah Kuala University. To get data such as observation and interviews, the researcher conducted research in the field to obtain the data needed. Research activities in this data collection process take approximately 3 weeks to get maximum results. The selection of subjects in this study were 5 Family Welfare Study Program of Teacher Training and Education Faculty of Syiah Kuala University students who had run a business for at least 6 months. To carry out this research, besides interview, the writer also carried out observations, documentation and literature. The data obtained are then grouped based on their respective problems according to the fact in the field, then summarized as information, summarized with supporting theories and then drew conclusions.

\section{Results And Discussion}

Based on the results of interviews with 5 respondents, the results were obtained as follow:

1. To find out the marketing strategy of the products and services of Family Welfare Study Program of Teacher Training and Education Faculty of Syiah Kuala University students who have already done

The results of interviews with respondents "A", according to respondent A, she is already familiar with the marketing strategy, which is the target of the business market among students and the public, so that consumers are interested in using products produced by respondent $\mathrm{A}$ using meat which is different from other business products, meat that was through selfprocessed then fried and using dark bread mixed with squid ink, so this becomes a unique thing in the market. Respondent A added that to make the businesses can still compete in the market is by maintaining the quality of products such as not using preservatives that can damage health and also pay attention to the quality of ingredients from the burgers.

The results of interviews with respondents "B", according to respondents B that she already understand about the marketing strategy, which is the target market for the business is the community around the location of the business and not also the Lecturers. Respondent $\mathrm{B}$ added that it was very rare to do direct promotions, but respondents B focused on neatness from the results of the stitches so that the customers would use their services again.

Followed by an interview with the respondent " $\mathrm{C}$ " said that she does not understand about the marketing strategy, the target market in the business of the respondent " $\mathrm{C}$ " is civil servants including School Teachers, Lecturers and Health Centre staff. With neat and timely sewing techniques is a way to maintain the product so that it can compete in the market.

And then interviewing respondents " $\mathrm{D}$ " also did not understand the marketing strategy, then respondent $\mathrm{D}$ added that the target market for his business was close relatives; his schoolmates and other relatives. Respondent D always put forward the quality of the product by paying attention to the right and neat sewing technique, currently the $\mathrm{D}$ respondent has a co-worker in sewing, even though the stitches from his co-worker is still checked first. During this time the promotion carried out was quite attractive, by giving a discount to customers who were able to bring other consumers to sew in his place. Respondent D considered this marketing strategy was effective enough.

Continued interviewing with the respondent "E" who said he did not know about the marketing strategy. The market target for his business is the people around Lambada Pekan 
village. Respondent E further said that to maintain products and services in order to be able to compete in the market is by maintaining product quality, both from neatness in sewing, and not forgetting to pay attention to making patterns properly, so that clothes are comfortable to wear.

2. To find out the marketing strategy of products and services that can be developed by Family Welfare Study Program of Teacher Training and Education Faculty of Syiah Kuala University students in the digital era.

The results of interviews with respondents "A" so far respondent A is very familiar with marketing in the digital era, and knows a lot of social media that can be used for marketing in the digital era. But for now respondents A prefer to use Instagram media, and WhatsApp as a promotional tool by broadcast to social media users. respondents A also ask his friends to help promote it to other friends. The impact of marketing through social media is very good, it is able to attract consumers and assisted with the features available on social media.

The results of interviews with respondents "B" in order to make consumers interested in using services of the business, respondent B used social media in the form of WhatsApp as a promotional tool and did not forget to make a pamphlet of business name, that is Argas Taylor, to make customer easier to find the addresses. The impact of the marketing was also effective enough to increase income. Furthermore, the results of interviews with respondents "C" who said the promotion that had been done using social media such as: facebook, Twitter, and Instagram. The impact of the promotion was very good, but respondents " $C$ " added that she was very rarely promotion via the internet as she was afraid to make customers disappointed because the order was full every month. Continued interviews with respondents "D" who already knew about marketing in this digital era, but it was the same with some other respondents, less optimizing the media that can be used because they do not have time for promotion and busy with other activities.

Furthermore, the results of interviews with respondents "E" the information was not much different from respondent $\mathrm{C}$. The promotions carried out so far use social media such as: facebook, Twitter, Instagram, but respondents E did not optimize marketing through these media, because they did not understand how to communicate and interact by online

\section{4 conclussion}

Based on the results of the research that has been done, it can be concluded that:

1. In order to make the businesses run by Family Welfare Study Program of Teacher Training and Education Faculty of Syiah Kuala University students can still compete in the market by paying attention to things such as: maintaining product quality, neat sewing techniques, making orders according to consumer demand, improving services to consumers and timely completion of consumer orders.

2. The presence of technology and information in the form of social media has brought changes to human life, especially in the aspect of behaviour, in which human activities becomes easier, so that it helps increase income of businessman

3. Family Welfare Study Program of Teacher Training and Education Faculty of Syiah Kuala University students had difficulties in marketing and less utilize of internet media in marketing their products. Only some of social media were used by businessman to market their products and attract consumers' interests for instance through Instagram, WhatsApp, Facebook and Line. So that the target market for Family Welfare Study Program of Teacher Training and Education Faculty of Syiah Kuala University students was still in the environment of close relatives and communities around the business location. 
4. Lack of knowledge about technology makes some businessman difficult to market their products and services so that they cannot increase their profits. Considering the condition of consumers that are increasingly smart and wise in choosing the items to be consumed.

\section{References}

[1] A. Robert, How to SELL The Right Way to Sell. Jakarta: Erlangga, 2005.

[2] Z. H. Frinces, Conception strategy Winning Business War, first print. Yogyakarta: Young Library, 2007.

[3] A. Thamrin and F. Tantri, Marketing Management. Jakarta: PT. Raja Grafindo Persada, 2014.

[4] S. Assauri, Marketing Management. Jakarta: PT. Prajagrafindo Persada, 2009.

[5] P. Kotler, Marketing, Analysis, Planning, Implementation and Control Management. Surakarta: PT. Label, 1997.

[6] I. Gemiharto, "4G-Lte Technology and Challenges," J. Commun. Stud., vol. 3, no. 2, pp. 212 220, 2015.

[7] E. Ardianto, Handbook of Public Relations. Bandung: Symbiosis Rekatama Media, 2011.

[8] B. Bungin, Qualitative Research Methodology. Jakarta: PT. Raja Grafindo Persada, 2001.

[9] Sugiyono, Quantitative, Qualitative and $R \& B$ Research Methods. Bandung: PT. Alfabeta, 2012. 